\title{
Arı sütü 10- Hidroksi-2-Dekanoik asit (10-HDA) miktarı ne olmalıdır?
}

\author{
What should be the amount of 10- Hydroxi-2-Decanoic Acid (10-HDA) in royal \\ jelly?
}

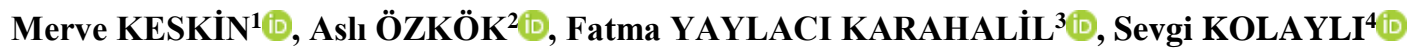

${ }^{1}$ Sağlık Hizmetleri Meslek Yüksek Okulu, Bilecik Şeyh Edebali Üniversitesi, Bilecik

${ }^{2}$ Hacettepe Arı ve Arıcıllk Araştırma ve Uygulama Merkezi, Hacettepe Üniversitesi, Ankara

${ }^{3}$ Karadeniz Teknik Üniversitesi, Maçka Meslek Yüksekokulu, Trabzon

${ }^{4}$ Karadeniz Teknik Üniversitesi, Fen Fakültesi, Trabzon

Sorumlu yazar (Corresponding author): M. Keskin, e-posta (e-mail): merveozdemirkeskin@gmail.com

Yazar(lar) e-posta (Author e-mail): asozkok@gmail.com, fkarahalil@hotmail.com, skolayli61@yahoo.com

\section{MAKALE BİLGISI}

Alınıs tarihi 04 Mart 2020

Düzeltilme tarihi 02 Haziran 2020

Kabul tarihi 25 Haziran 2020

Anahtar Kelimeler:

10-HDA

Ar1 sütü

Yağ asidi

\begin{abstract}
$\ddot{O Z Z}$
Arı sütü binlerce çiçekten özümsenen nektar ve çiçek polenleri ile bal arılarının enzimlerini de içeren, akıcı jel halinde ve kremsi-beyaz renkteki etkili bir salgıdır. Besin değeri yüksek bu ürün amino asit, peptit, protein ve minerallerden oluşur. Arı sütünün en önemli özelliği diğer arı ürünlerinde bulunmayan kısa zincirli hidroksi yağ asitlerince zengin oluşudur. Antibakteriyel, anti-tümoral, ve immün sistemi uyarıc özelliğe sahip arı sütünün majör yağ asidi trans-10-hidroksi-2-dekanoik asit (10-HDA)'dır. Yapılan bu calıșa ile farklı yıllarda toplanan arı sütü örneklerinin nem ve 10-HDA miktarı tayin edildi. HPLC-UV ile ölçülen 10HDA miktarının yıllara göre ortalama \%2.1 ile \%2.6 arasında değiştiği tespit edildi. Arı sütü nem içeriğinin ise ortalama $\% 62.6$ ile $\% 66.5$ arasında değiştiği tespit edildi.
\end{abstract}

\section{ARTICLE INFO}

Received 04 March 2020

Received in revised form 02 June 2020

Accepted 25 June 2020

Keywords:

10-HAD

Royal jelly

Fatty acid

\begin{abstract}
Royal jelly is an effective secretion of creamy-white color with flowing gel that contains nectar of thousands of flower pollen and enzymes of honey bees. Royal jelly is very rich in nutritional value. It contains a wide variety of enzymes, peptides and amino acids. There are short-chain hydroxy fatty acids found in royal jelly but not found in other foods, which are claimed to have anti-tumor, anti-bacterial, and immune regulatory activity. Trans-10-hydroxy2-decanoic acid (10-HDA) is the major fatty acid in royal jelly and its amount in royal jelly is an important indicator. In this study, 10-HDA, in royal jelly samples collected in different years, were determined by using HPLC-UV. The moisture content of royal jelly samples was determined gravimetrically. It was found that the amount of 10-HDA varied between 2.1 and $2.6 \%$ on average per year. It was determined that the moisture content of royal jelly was between $62.6 \%$ and $66.5 \%$ on average.
\end{abstract}

\section{Giriş}

Apiterapi arı ve arı ürünlerinin bazı hastalıkların tedavisinde tamamlayıcı ve destekleyici olarak kullanılmasıdır (GETAT Yönetmeliği 2014). Arı zehri başta olmak üzere, bal, polen ve arı sütünün apiterapide doğrudan kullanımı oldukça yaygındır.

Ar1 sütü işçi arıların hipofaringeal (boğaz) ve mandibular glandlarından (alt çene) salgılanır ve ana arının larva döneminde ve yaşam süresi boyunca önemli rol oynar (Tamura ve ark. 2009). Ar1 sütü binlerce çiçekten özümsenen nektar ve çiçek polenleri ile bal arılarının enzimlerini de içeren, akıcı jel halinde ve kremsi-beyaz renkteki etkili bir karışımdır. Çok çeşitli vitamin, enzim, protein, peptitler ve aminoasitler içerir. Bu nedenle ar1 sütü yüksek besin değerine sahiptir.
Ana arı ve işçi arılar yumurta dönemlerinde aynı genetik yapıya sahiptirler. Fakat larva dönemlerinde ana arının işçi arılara göre farklı oranlarda ve sürelerde, yüksek kalitede arı sütü ile beslenmesi nedeniyle anatomik, fizyolojik ve morfolojik yapılarında belirgin farklılaşmalar meydana gelir. Sadece 6 günlük bu farklı beslenme sonucunda ana arı hastalıklara direnç kazanmakta, günde kendi ağırlığının iki katı kadar (1500-3000) yumurta üretebilmekte ve 3-5 yıl kadar yaşayabilmektedir. İşçi arılar ise, zayıf immün sistemlerinden dolayı daha kolay hastalanırlar, dişi oldukları halde yumurta bırakamazlar ve sadece 2-3 ay yaşarlar. İki birey arasındaki bu derece farklılaşmanın temel nedeninin arı sütü ile beslenmelerinden kaynaklandığı ileri sürülmektedir (Kolayli ve ark. 2015). Arı 
sütü genel olarak vücutta hücre yenilenmesi, üretimi ve metabolizması üzerinde etkili olduğundan organizmanın bütün dokularında canlılık ve bunun sonucunda sağlik, enerji, bağışıklık ve dinçlik kazandırdığı bilinmektedir. Bu yönüyle akla gelecek bütün sağlık sorunlarında kullanılması yönünde çalışmalar bir hayli artmıştır. Arı sütünün antioksidan, sinir sistemini düzenleyici, kanda şeker ve kolesterolü düşürücü, karaciğeri koruyucu, tansiyonu düşürücü ve kan basıncını düzenleyici, anti-tümör, antibiyotik, anti-inflamatuar, bağışıklık sistemini düzenleyici, anti alerjik, genel tonik ve anti-aging gibi farmakolojik özelliklere sahip olduğu bildirilmektedir (Pavel ve ark. 2011). Bu özelliklerinden dolayı arı sütü pek çok ülkede ticari bir üründür ve medikal ürünlerde, gıdalarda ve kozmetiklerde yaygın bir şekilde kullanılmaktadır (Nagai ve ark. 2004).

Arı sütünde bulunup diğer gıdalarda bulunmayan ve antitümor, anti-bakteriyel ve immun sistemi düzenleyici aktivitesi ve hormonal etkinliği olduğu ileri sürülen kısa zincirli hidroksi yağ asitleri bulunmaktadır. Arı sütünün kuru ağırlığının \%3-\%19 arasında lipit içerdiği, yağ asitlerinin nötrallipitler, steroidler, hidrokarbonlar olduğu belirtilmiştir (Ramadana ve Ghamdi 2012; Terada ve ark. 2011). Arı sütü yağ asitleri daha çok kısa zincirli 8-10 karbonlu dikarboksilik asitler gibi çoğu bitki ve hayvanlarda bulunmayan yağ asitleridir (Ramadana ve Ghamdi 2012). Arı sütünde majör yağ asidi olarak kabul edilen trans-10-hidroksi-2-dekanoik asit (10-HDA) (Şekil 1) ar1 sütü için bir marker olarak kabul edilir ve arı sütünün kuru ağırlı̆̆ının yaklaşık \%0.5-\%3.5'ini 10-HDA'nın oluşturduğu ifade edilmektedir (Kamakura ve ark. 2001; Garcia-Amoedo ve ark. 2007; Liu ve ark. 2008; Ramadana ve Ghamdi 2012; Kanelis ve ark. 2015; Yukunc 2019).

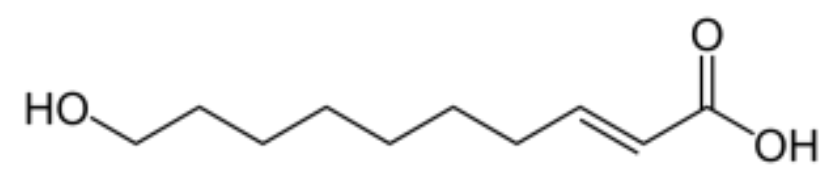

Şekil 1.10-Hidroksi-2-dekanoik asit (10-HDA).

Figure 1. 10-Hydroxy-2-decanoic acid (10-HDA).

Ülkemizde tüketim miktarı gittikçe artan arı sütünün üretim miktarında da artış bulunmaktadır. Artan talep karşısında arı sütünde tağşiş olup olmadığını tespit edebilmenin yollarından biri de arı sütü için önemli bir bileşeni olan 10-HDA miktarını belirlemektir. $\mathrm{Bu}$ nedenle arı sütü 10-HDA miktarı oldukça önem arz etmektedir. Yapılan bu çalışma ile Türkiye'de farklı y1llarda toplanan arı sütlerinin 10-HDA ve nem miktarları tespit edildi. Arı sütü nem miktarı ile 10-HDA miktarının yıllara göre değişimi belirlenerek nem miktarı ve 10-HDA miktarı arasında ilişki olup olmadığı tespit edildi.

\section{Materyal ve Metot}

\subsection{Arl sütü temini}

Arı sütü örnekleri Türkiye'de üretim yapan tecrübeli arıcılardan temin edildi. Arı sütü örneklerinin toplandığı iller Şekil 2'de belirtildi. Arıcılardan toplanan örnekler liyofilize edildi ve analiz yapılıncaya kadar $-18^{\circ} \mathrm{C}$ ' de saklandı. 2015 y1lında 3 örneğin, 2016 yılında 4 örneğin, 2017 y1lında 6 örneğin, 2018 y1lında 30 örneğin ve 2019 yılında ise 62 örneğin analizi yapıld1.

\subsection{Nem miktarı tayini}

Nem tayini için her örnekten ayrı ayrı $1 \mathrm{~g}$ tartıldı. Daha sonra 3 saat boyunca $105^{\circ} \mathrm{C}$ 'de bekletildi. Süre sonunda arı sütü örnekleri sabit tartıma gelene kadar desikatörde soğutuldu. Bu işlem her bir örnek için üç kez tekrarlandı (Horwitz ve Latimer 2000).

\subsection{0-HDA miktarı tayini}

10-HDA miktarı ultraviyole absorbans dedektörlü yükssek performansli sıv1 kromotografisi (HPLC, VWR Hitachi Chromaster HPLC-UV) cihazı kullanılarak belirlendi. Ölçümler en yüksek absorbans değerinin elde edildiği $215 \mathrm{~nm}$ 'de yapıldı (Kim ve Lee 2010). C-18 (150 x 4.6 mm) kolonun kullanıldığ çalışmada mobil faz metanol, su ve fosforik asit (55: 45: 2.2) ve akış hızı $1.0 \mathrm{~mL} \mathrm{~min}^{-1}$ olarak optimize edildi, numune enjeksiyon hacmi $3 \mu \mathrm{L}$ olarak belirlendi (Kim ve Lee 2010). Standart olarak metil 4-hidroksibenzoat (MHB) kullanıldı. Kalibrasyon çözeltileri $160 \mu \mathrm{g} \mathrm{mL}^{-1}$ stok 10-HDA çözeltisinin $\left(0.1, \quad 0.5,1.0,5.0,10,20,40,80\right.$ ve $\left.160 \mu \mathrm{g} \mathrm{mL} \mathrm{mL}^{-1}\right)$ seyreltilmesiyle elde edildi. Elde edilen kalibrasyon grafiğinin $\mathrm{R}^{2}$ değeri 0.9998 olarak belirlendi.

\subsection{Istatistik}

Elde edilen deneysel verilerin ortalama, standart sapma değerleri ve korelasyon katsayısı Microsoft excel programı kullanılarak hesaplandı.

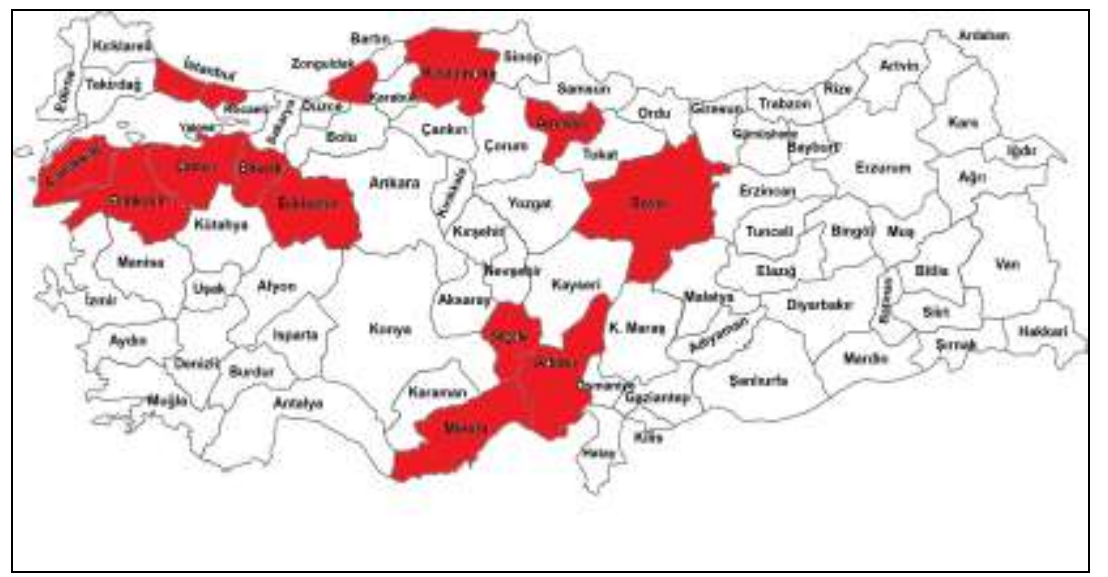

Şekil 2. Arı sütü örneklerinin toplandığı iller.

Figure 2. Provinces where royal jelly samples collected. 


\section{Bulgular}

\subsection{Nem miktarl tayini}

Yapılan analizler neticesinde arı sütü nem içeriğinin yıllara göre ortalama $\% 62.6 \pm 0.5$ ile $\% 66.5 \pm 1.0$ arasında değiştiği tespit edildi (Şekil 3).

\subsection{0-HDA miktarı tayini}

Elde edilen verilere göre arı sütü 10-HDA içeriği yıllara göre ortalama $\% 2.1 \pm 0.17$ ile $\% 2.6 \pm 0.10$ arasında değiştiği belirlendi (Şekil 4 ve Şekil 5). Nem miktarı ve 10-HDA miktarı arasındaki korelasyon katsayısı 0.68 olarak hesaplandı.

\section{Tartışma}

Apiterapi uygulamalarının yaygınlaşmasıyla birlikte fonksiyonel gıda olarak kullanımı artan arı sütü yüksek besin içeriği ile büyümeyi tetiklediği, bağışıklık sistemini, nörogenezi ve hafızayı güçlendirdiği, diyabet, kalp damar hastalıkları, yaşlanma ve metabolik sendroma karşı koruyucu olduğu, üreme hücrelerinin sayı ve kalitesini iyileştirdiğgi, yara iyileşmelerini kolaylaştırdığı, anti-bakteriyel, antiviral, antifungal, antiinflamatuar ve antitümoral aktivite gibi foksiyonel pek çok özelliğe sahip olduğu bildirilmektedir (Uçar 2018).

Ar1 sütünün \%60-70 arasında su, \%10-16 arasında protein, \%7-13 total şeker oranına sahip olduğu Fransız arı sütleri ile yapılan çalışma ile bildirilmiş ve bu çalışmada 10-HDA değerinin \%1.4 ile \%3.7 arasında değiştiği rapor edilmiştir (Wytrychowski ve ark. 2013). Arı sütü kompozisyonun sezona, ekolojik şartlara ve toplandığı bölgenin özelliklerine bağlı olduğu bildirilmektedir (Zheng ve ark. 2010). Elde edilen verilerin bu ifade ile uyumlu olduğu tespit edildi. Kolayli ve ark. (2015) tarafindan yapılan çalışmada Anadolu arı sütlerinin 10-HDA değerlerinin \%1 ile \%3.9 ve nem miktarının \%62.6 ile $\% 73$ arasında değiştiği ifade edilmektedir. Ayrıca uluslararası ar1 sütü standardı olan ISO/DIS 12824 (2016)'e göre arı sütü 10-HDA değerinin minimum \%1.4 nem miktarı ise minimum \%62 maksimum \% 68.5 olması gerektiği ifade edilmektedir. Yapılan bu çalışma neticesinde nem miktarı ve 10-HDA miktarı arasındaki korelasyon katsayısı 0.68 olarak hesapland. Bu durum nem miktarı ve 10-HDA arasında zayıf bir ilişki olduğunu göstermektedir.

Yavuz ve Gürel (2017) yapmış oldukları çalışmada ticari arı sütü örneklerinin 10- HDA miktarlarının $\% 0.75$ ile $\% 3.11$ arasında değiştiği nem miktarının ise $\% 63.1$ ile $\% 73.5$ arasında değiştiği ifade edilmektedir. Fakat uluslararası arı sütü standardına göre (ISO/DIS 12824 2016) arı sütü 10-HDA değerinin minimum \%1.4 olması gerekmektedir. Bu değerin altında 10-HDA içeren örneklerin arı sütü olmama ya da katkılı ürün olma ihtimali oldukça yüksek olduğu ifade edilmiştir (Yavuz ve Gürel 2017).

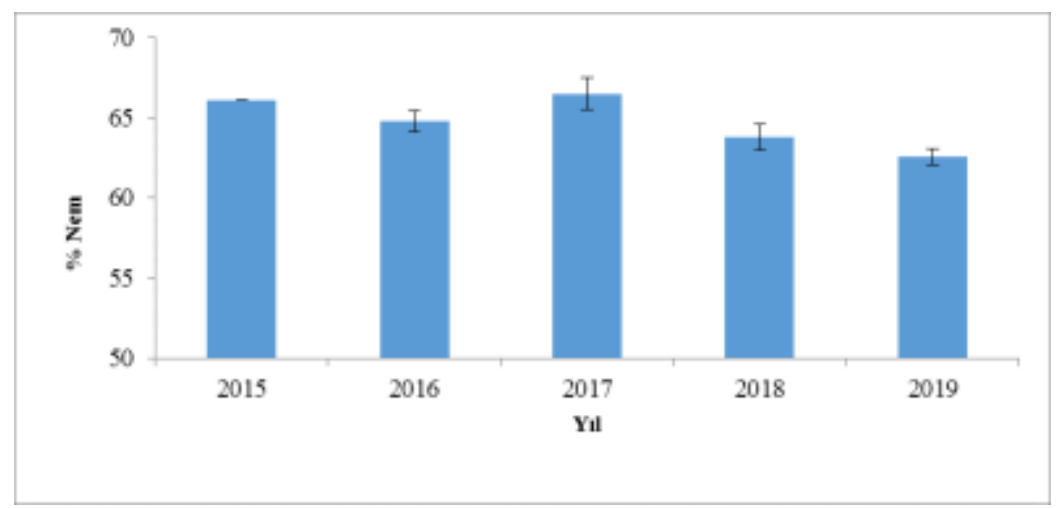

Şekil 3. Farklı yıllarda üretilmiş arı sütlerinin ortalama nem miktarları.

Figure 3. Mean value of moisture content (\%) for royal jelly in different years.

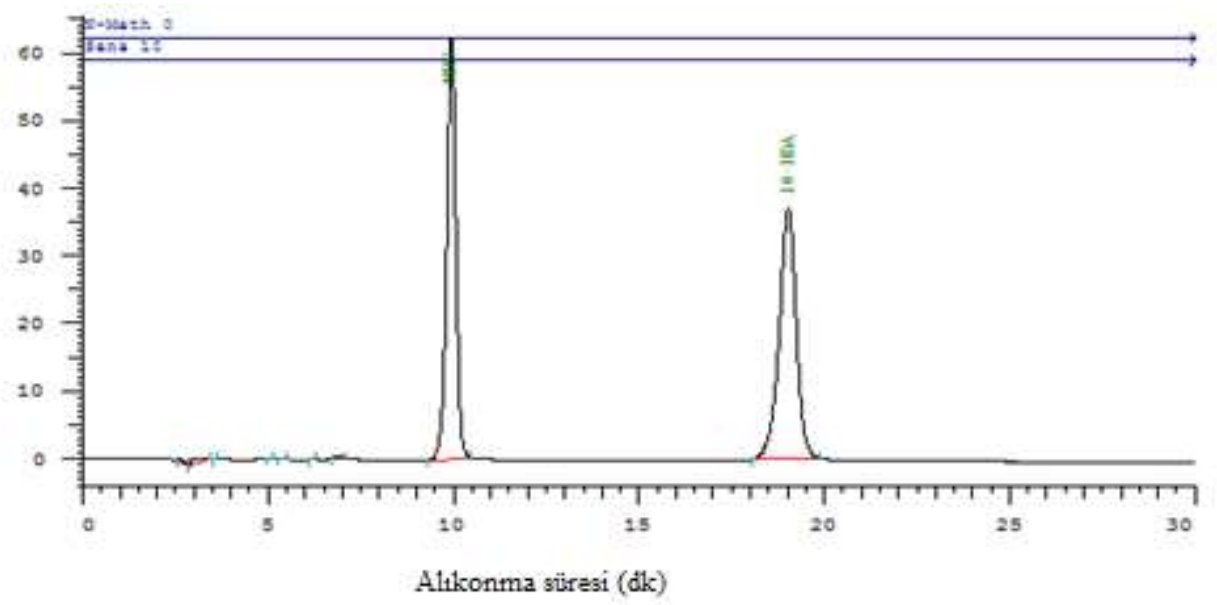

Şekil 4. 10-HDA kromotogramı: 1: Internal standard metil-4-hidroksibenzoat(MHB) 2: 10-HDA.

Figure 4. Choromatogram of 10-HDA: 1: Internal standard (MHB), 2: 10-HDA. 


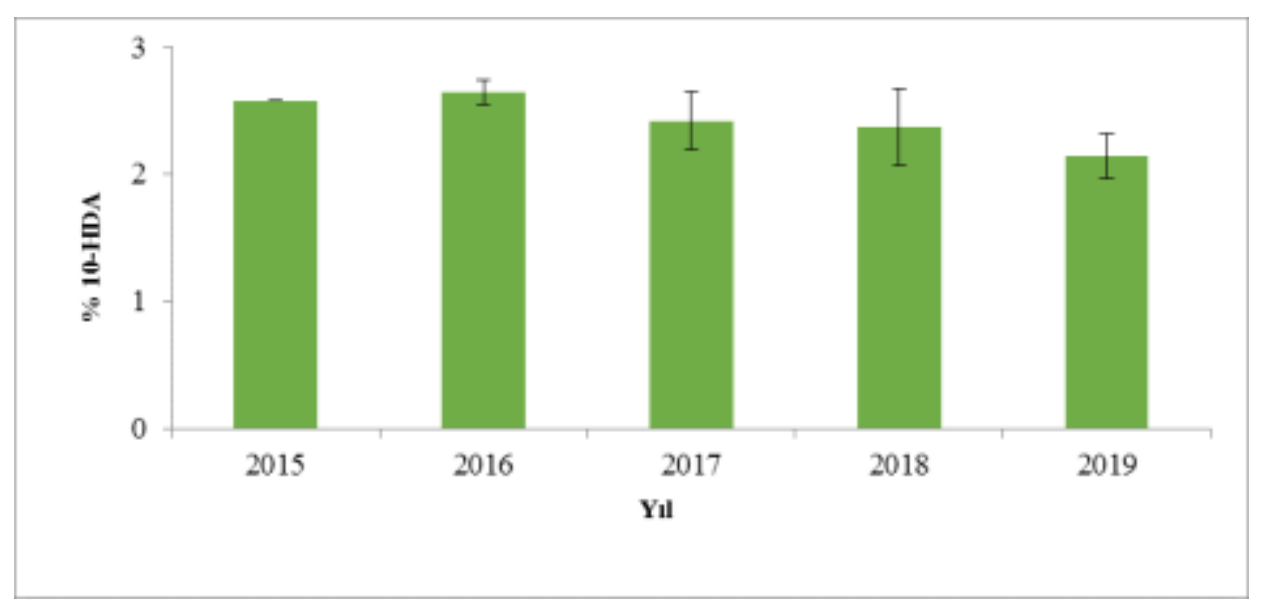

Şekil 5. Farklı yıllarda üretilmiş arı sütlerinin ortalama 10-HDA miktarları.

Figure 5. Mean value of 10-HDA in different years.

\section{Sonuç}

Geleneksel ve tamamlayıcı tıp uygulamalarında ve gida takviyesi olarak arı ürünlerinin kullanımının artması nedeniyle arı sütüne olan ihtiyaç artmıştır. Arı sütü kısa zincirli hidroksi yağ asitleri açısından zengindir. Bu yağ asitlerinden olan 10HDA arı sütü için önemli bir kalite parametresidir. Ön çalışma niteliğinde olan bu çalışma ile Türkiye'de üretimi yapılan arı sütü örneklerinin 10-HDA içeriği belirlenerek Türk arı sütü örneklerinin yıllara göre 10-HDA profilleri ortaya çıkarılmış böylelikle artan talep karşısında ticari arı sütü örneklerinin içermesi gereken 10-HDA miktarının olması gereken değer aralığı belirlenmiştir.

\section{Teşekkür}

Ar1 sütü örneklerinin temininde desteklerini esirgemeyen Bee\&You (Bee'O ${ }^{\circledR}$, SBS Scientific Bio Solutions Inc, İstanbul, Türkiye) firmasına teşekkür ederiz.

\section{Kaynaklar}

Garcia-Amoedo LH, Almeida-Muradian LB (2007) Physicochemical composition of pure and adulterated royal jelly. Química Nova 30(2): 257-259.

GETAT Yönetmeliği (2014) Resmi gazete, 29158.

Horwitz W, Latimer G (2000) Official methods of analysis of AOAC International. Gaithersburg MA, USA: Association of Official Analytical Chemist.

ISO/DIS 12824 (2016) Royal jelly specifications AFNOR/ABNT.

Kamakura M, Mitani N, Fukuda T, Fukushima M (2001) Antifatigue effect of fresh royal jelly in mice. Journal of Nutritional Science and Vitaminology 47: 394-401.

Kanelis D, Tananaki C, Liolios V, Dimou M, Goras G, Rodopoulou MA, Karazafiris E, Thrasyvoulou A (2015) A suggestion for royal jelly specifications. Archives of Industrial Hygiene and Toxicology 66: $275-284$.

Kim J, Lee J (2010) Quantitative analysis of trans-10-hydroxy decenoic acid in royal jelly products purchased in USA by high performance liquid chromatography. Journal of Apicultural Science 54: 77-86.

Kolayli S, Sahin H, Can Z, Yildiz O, Malkoc M, Asadov A (2015) Member of complementary medicinal food: Anatolian royal jellies, their chemical compositions, and antioxidant properties. Journal of Evidence-Based Complementary \&Alternative Medicine 21(4): 4348 .
Liu JR, Yang YC, Shi L, Peng C (2008) Antioxidant properties of royal jelly associated with larval age and time of harvest. Journal of Agricultural and Food Chemistry 56: 11447-11452.

Nagai T, Nagashima T, Myoda T, Inoue R (2004) Preparation and functional properties of extracts from bee bread. Nahrung Food 48: 226-229.

Pavel CI, Mărghitaş LA, Bobiş O, Dezmirean DS, Şapcaliu A, Radoi I, Mădaş MN (2011) Biological activities of royal jelly. Scientific Papers. Journal of Animal Science and Biotechnology 44: 108-118.

Ramadana MF, Al-Ghamdi A (2012) Bioactive compounds and healthpromoting properties of royal jelly: A Review. Journal of Functional Foods 4: 39-52.

Tamura S, Amano S, Kono T, Kondoh J, Yamaguchi K, Kobayashi S (2009) Molecular characteristics and physiological functions of major royal jelly protein 1 oligomer. Proteomics 9: 5534-5543.

Terada Y, Narukawa M, Watanabe T (2011) Specific hydroxy fatty acids in royal jelly activate TRPA1. Journal of Agricultural and Food Chemistry 59: 2627-2635.

Uçar M (2018) Arı sütünün diyabet, tümör oluşumu ve metabolik sendrom üzerine etkisi. Online Türk Sağlık Bilimleri Dergisi 3(2): 101-112.

Wytrychowski M, Chenavas S, Daniele G, Casabianca H, Batteau M, Guibert S, Brion B (2013) Physicochemical characterisation of French royal jelly: Comparison with commercial royal jellie sand royal jellies produced through artificial bee-feeding. Journal of Food Composition and Analysis 29: 126-133.

Yavuz İ, Gürel F (2017) Chemical properties of the royal jellies in turkish markets. Mediterranean Agricultural Sciences 30(3): 281285.

Yukunc GO (2019) Royal jelly: Proteins and peptides. Journal of Apitherapy and Nature 2(2):59-70.

Zheng HQ, Hu FL, Dietemann V (2010) Changes in composition of royal jelly harvested at different times: Consequences for quality standards. Apidologie 42(1): 39-47. 